\title{
The Effect of Framingham Score on the Oncological Outcomes in Localized (T1-T2 Stage) Renal Cell Carcinoma Patients
}

\author{
(๑) İsmail Selvi MD¹, ๑ Halil Başar MD² \\ 1 Karabük University Training and Research Hospital, Clinic of Urology, Karabük, Turkey \\ 2 Health Sciences University, Dr. Abdurrahman Yurtaslan Ankara Oncology Training and Research Hospital, Clinic of Urology, Ankara, Turkey
}

\begin{abstract}
Objective: To evaluate the effect of cardiovascular disease risk on local recurrence, distant metastasis development and cancer-specific survival in patients with localized (stage 1 and 2) renal cell carcinoma (RCC).

Materials and Methods: Data of patients who underwent partial or radical nephrectomy due to pathological stage 1 and 2 RCC between September 2009 and July 2016 were retrospectively evaluated. Ninety-six patients with fully accessible data were included in the study. Demographic data, histological tumor type, Fuhrman grading, local recurrence, metastasis and survival after nephrectomy were recorded. Framingham risk score, which predicts cardiovascular disease within 10 years, was calculated in all patients. The patients were divided into three groups as low (group 1), moderate (group 2) and high risk (group 3).

Results: Mean age of patients was $58.66 \pm 10.55$ years at the time of nephrectomy. Nine (9.4\%) patients had local recurrence, $12(12.5 \%)$ had distant metastasis and $11(11.5 \%)$ died due to cancer during a median follow-up period of 57 (6-102) months. Regarding intergroup comparison, local recurrence rate $(21.9 \%, p=0.012)$ and distant metastasis rate $(25 \%, p=0.025)$ were significantly higher in group 3 , and predicted recurrence-free survival (66.4 months, $p=0.005)$, metastasis-free survival ( 77 months, $p=0.017)$ and cancer-specific survival $(79.9$ months, $p=0.024)$ were found to be significantly lower. In univariate analysis, body mass index, total cholesterol level, estimated glomerular filtration rate and Framingham risk score were independent predictive factors for local recurrence, distant metastasis development and cancer-specific survival. In multivariate analysis, body mass index, estimated glomerular filtration rate and Framingham risk score were more significant.

Conclusion: Patients who are at high risk of developing cardiovascular disease have more local recurrence, distant metastasis and cancer-specific mortality rates, even though nephrectomy is performed due to localized RCC. Therefore, we suggest that these patients should be followed more carefully in the post-nephrectomy period.
\end{abstract}

Keywords: Cardiovascular disease risk, Framingham risk score, nephrectomy, oncologic outcomes, renal cell carcinoma

\section{Introduction}

Renal cell carcinoma (RCC) with increased rates of incidental detection during the localized stage (stage 1-2) with a small size accounts for $2-3 \%$ of all cancers (1). Its incidence increases in the sixth and seventh decades, and known predisposing factors are smoking, obesity and hypertension (2).

Although the presence of tumor-related anatomical and histological factors [tumor-node-metastasis (TNM) stage, Fuhrman tumor grade, histological type, tumor size, presence of necrosis, etc.] and patient-related factors (clinical signs, symptoms, general health status, laboratory findings, molecular factors) is known (3), the importance of new molecular markers continues to be investigated with current studies $(4,5,6)$. In localized RCC patients, local recurrence or distant metastasis rates after partial or radical nephrectomy have been reported to be $20-40 \%$ (7). The effects of presence and components of metabolic syndrome on oncologic outcomes in localized RCC have been investigated in many studies. The common belief in these studies is that the metabolic syndrome is a poor prognostic factor for RCC, that it increases the incidence of RCC approximately 4-6 times, leads to an increase in tumor size and stage, and significantly reduces progression-free survival (PFS) $(8,9,10)$. Hypertension was found to be the worst prognostic risk factor in the publications investigating the effects of 
individual metabolic syndrome components on oncologic outcomes in RCC $(11,12)$. However, there are no studies in the literature that predict post-nephrectomy outcomes according to developing 10-year cardiovascular disease risk.

In our study, we aimed to investigate the effect of cardiovascular disease risk, calculated according to Framingham score before nephrectomy, on the local recurrence, distant metastasis and cancer-related mortality rates in patients with pathologic stage 1-2 RCC.

\section{Materials and Methods}

We retrospectively evaluated 148 patients who underwent partial or radical nephrectomy due to localized RCC, and whose pathological diagnosis was stage 1 or 2 RCC according to TNM classification in our clinic between September 2009 and July 2016. The demographic data of the patients, histological tumor type, Fuhrman grading, presence of necrosis, tumor side, localization, size, type of surgery, follow-up period after nephrectomy, local recurrence, metastasis and survival rates were recorded. Estimated glomerular filtration rate (eGFR), calculated by the short-term Modification of Diet in Renal Disease (MDRD) formula using preoperative creatinine, age, gender and race, was recorded.

\section{Framingham Risk Score}

The Framingham risk score was prepared according to longterm studies of National Cholesterol Education Program Adult Treatment Panel 3 (NCEP ATP 3) and National Heart, Lung and Blood Institute and it is based on research in 1976. It was first tried in 1998 in daily practice and it is used to estimate the 10-year cardiovascular (myocardial infarction, coronary death, angina, etc.) risk of an individual. Reliability and validity have been provided by various studies (13). The Framingham score, which is one of the most commonly used risk calculations, systematically predicts the risk of cardiovascular disease and related mortality by systematic mathematical equations (14). The aim of this risk score is to determine measurable and preventable risk factors that can affect the development of cardiovascular disease, to provide lifestyle and behavior change in patients at risk and to determine appropriate treatment.

The Framingham risk calculator, developed for patients between the ages of 30-74, only calculates 10-year cardiovascular event risk (total of non-fatal and fatal coronary events). The parameters used in the Framingham risk score include risk factors associated with coronary heart disease, such as age, gender, blood pressure, total cholesterol, high density lipoprotein (HDL) levels, smoking, and diabetes. Scoring is performed for each parameter and the total score is calculated. The percentages that correspond to the specified score range refer to the 10-year risk of developing cardiovascular disease separately for men and women. According to this, $<10 \%$ indicates a low-risk, 10-20 $\%$ a moderate-risk and $>20 \%$ a high risk (15). This risk score is both easy to implement and does not require additional invasive intervention or cost because the necessary data can be easily obtained in clinical practice.

The data required to calculate Framingham risk score of patients included in the study, which include age, gender, total cholesterol, HDL level, systolic blood pressure, use of antihypertensive treatment, smoking, and diabetes, were obtained from hospital archive and patient information system. These data were used in the calculation of Framingham score in the week immediately preceding nephrectomy. Ninety-six patients with complete data were included in the study without randomization. According to the Framingham risk score, the patients were divided into three groups as low-risk $(<10 \%)$, moderate-risk (10-20\%) and high risk (>20\%) respectively, and were named as group 1, 2 and 3, respectively. Three groups were compared in terms of oncologic outcomes.

\section{Statistical Analysis}

To compare the differences between the three groups, Pearson chi-square was used for categorical variables, One-way analysis of variance (ANOVA) or Kruskal-Wallis test were used for continuous variables. Tukey or Dunn-Bonferroni tests were applied for multiple comparisons. Kaplan-Meier was used for survival analysis and Cox regression analysis was used to determine the variables that affect this. Spearman test was used for correlation analysis. Analysis was performed using IBM SPSS Statistics 21 (IBM, Armonk, NY USA) software. $p<0.05$ was considered statistically significant.

\section{Results}

The mean age of the 96 patients included in the study was $58.66 \pm 10.55$ years, and $56(58.3 \%)$ were male and $40(41.7 \%)$ were female. During the median follow-up period of 57 (6-102) months, nine (9.4\%) patients had local recurrence, 12 (12.5\%) had distant metastasis and 11 (11.5\%) died due to cancer. Distant metastases were seen in lung in six patients, bone in two patients and liver in four patients. Demographic, pathological, clinical data and oncologic outcomes of the patients are shown in Table 1.

Regarding intergroup comparisons, local recurrence rate (21.9\%, $\mathrm{p}=0.012)$ and distant metastasis rate $(25 \%, \mathrm{p}=0.025)$ were significantly higher in group 3 (Table 1 ). The predicted recurrence-free survival in group 3 (66.4 months) was significantly lower than in group 1 (98.9 months) and group 2 (99.2 months) ( $p=0.021$ and $p=0.010$, respectively). No significant difference was observed between the predicted recurrence-free survivals of the patients in group 1 and group 2 $(\mathrm{p}=0.935)$ (Table 2, Figure 1$).$

The predicted metastasis-free survival in group 3 (77 months) was significantly lower than in group 1 (92.2 months) $(p=0.013)$. There was no significant difference between survival in group 2 (94.5 months) and group 1 and group 3 patients ( $\mathrm{p}=0.404$ and $\mathrm{p}=0.061$, respectively) (Table 2, Figure 2 ).

The predicted cancer-specific survival in group 3 (79.9 months) was significantly lower than in group 1 (102 months) $(p=0.007)$. There was no significant difference between predicted cancerspecific survival in group 2 (94.7 months) and group 1 and group 3 ( $\mathrm{p}=0.401$ and $\mathrm{p}=0.128$, respectively) (Table 2, Figure $3)$.

In the univariate analysis, body mass index (BMI), total cholesterol level, eGFR and Framingham risk score were independent predictive factors for local recurrence, distant metastasis and cancer-specific survival. In multivariate analysis, 
Selvi and Başar

The Importance of Framingham Score in Renal Cell Carcinoma

\begin{tabular}{|c|c|c|c|c|c|}
\hline Parameters & Group $1(n=31)$ & Group $2(n=33)$ & Group $3(n=32)$ & Total $(n=96)$ & $\mathrm{p}$ \\
\hline Age, mean \pm standard deviation & $54.84 \pm 11.17^{\mathrm{a}}$ & $61.30 \pm 9.32^{\mathrm{b}}$ & $59.63 \pm 10.39^{\mathrm{ab}}$ & $58.66 \pm 10.55$ & $\dagger 0.039 *$ \\
\hline $\begin{array}{l}\text { Gender }(n, \%) \\
\text { Male } \\
\text { Female }\end{array}$ & $\begin{array}{l}17(54.8) \\
14(45.2) \\
\end{array}$ & $\begin{array}{l}19(57.6) \\
14(42.4)\end{array}$ & $\begin{array}{l}20(62.5) \\
12(37.5) \\
\end{array}$ & $\begin{array}{l}56(58.3) \\
40(41.7)\end{array}$ & $\$ 0.822$ \\
\hline $\begin{array}{l}\mathrm{BMI}\left(\mathrm{kg} / \mathrm{m}^{2}\right) \\
\text { (median, } 25^{\text {th }}-75^{\text {th }} \text { percentile) }\end{array}$ & $\begin{array}{l}23.3 \\
(21.3-24.4)^{\mathrm{a}} \\
\end{array}$ & $\begin{array}{l}23.6 \\
(21.9-26.2)^{\mathrm{a}}\end{array}$ & $\begin{array}{l}27.6 \\
(24.5-29.0)^{b}\end{array}$ & $\begin{array}{l}24.2 \\
(22.3-26.8)\end{array}$ & $\S 0.226 /<0.001 /<0.001 *$ \\
\hline $\begin{array}{l}\text { Smoking } \\
\text { Yes } \\
\text { No }\end{array}$ & $\begin{array}{l}13(41.9) \\
18(58.1)\end{array}$ & $\begin{array}{l}22(66.7) \\
9(27.3)\end{array}$ & $\begin{array}{l}25(78.1) \\
9(21.9)\end{array}$ & $\begin{array}{l}60(62.5) \\
36(37.5)\end{array}$ & $\$ 0.016 *$ \\
\hline $\begin{array}{l}\text { Hypertension } \\
\text { Yes } \\
\text { No }\end{array}$ & $\begin{array}{l}1(3.2) \\
30(96.8) \\
\end{array}$ & $\begin{array}{l}9(27.2) \\
24(72.8) \\
\end{array}$ & $\begin{array}{l}17(53.1) \\
15(46.9)\end{array}$ & $\begin{array}{l}27(28.1) \\
69(71.9)\end{array}$ & $\$<0.001^{*}$ \\
\hline $\begin{array}{l}\text { Diabetes } \\
\text { Yes } \\
\text { No }\end{array}$ & $\begin{array}{l}3(9.7) \\
28(90.3)\end{array}$ & $\begin{array}{l}5(15.2) \\
28(84.8)\end{array}$ & $\begin{array}{l}15(46.9) \\
17(53.1)\end{array}$ & $\begin{array}{l}23(23.9) \\
73(76.1)\end{array}$ & $+0.001 *$ \\
\hline $\begin{array}{l}\text { Surgery } \\
\text { Radical } \\
\text { Partial }\end{array}$ & $\begin{array}{l}20(64.5) \\
11(35.5) \\
\end{array}$ & $\begin{array}{l}23(69.7) \\
10(30.3)\end{array}$ & $\begin{array}{l}25(78.1) \\
7(21.9) \\
\end{array}$ & $\begin{array}{l}68(70.8) \\
28(29.2) \\
\end{array}$ & +0.486 \\
\hline $\begin{array}{l}\text { Tumor side } \\
\text { Right } \\
\text { Left }\end{array}$ & $\begin{array}{l}14(45.2) \\
17(54.8) \\
\end{array}$ & $\begin{array}{l}17(51.5) \\
16(48.5) \\
\end{array}$ & $\begin{array}{l}15(46.9) \\
17(53.1) \\
\end{array}$ & $\begin{array}{l}46(47.9) \\
50(52.1) \\
\end{array}$ & $\$ 0.87$ \\
\hline $\begin{array}{l}\text { Tumor localization } \\
\text { Upper pole } \\
\text { Middle pole } \\
\text { Lower pole } \\
\text { Hilum }\end{array}$ & $\begin{array}{l}9(29) \\
8(25.8) \\
12(38.7) \\
2(6.5) \\
\end{array}$ & $\begin{array}{l}7(21.2) \\
8(24.2) \\
14(42.5) \\
4(12.1) \\
\end{array}$ & $\begin{array}{l}10(31.3) \\
6(18.8) \\
7(21.9) \\
9(28) \\
\end{array}$ & $\begin{array}{l}26(27) \\
22(22.9) \\
33(34.3) \\
15(15.8) \\
\end{array}$ & +0.209 \\
\hline $\begin{array}{l}\text { Pathological tumor size }(\mathrm{cm}) \\
\text { (median, } 25^{\text {th }}-75^{\text {th }} \text { percentile) }\end{array}$ & $\begin{array}{l}4.4 \\
(3.2-5.5)\end{array}$ & $\begin{array}{l}4.6 \\
(2.7-6)\end{array}$ & $\begin{array}{l}4.5 \\
(3-5.8)\end{array}$ & $\begin{array}{l}4.4 \\
(3.02-5.95)\end{array}$ & $\S 0.98$ \\
\hline $\begin{array}{l}\text { Histological subtype, }(n, \%) \\
\text { Clear cell } \\
\text { Papillary } \\
\text { Chromophobe } \\
\text { Other }\end{array}$ & $\begin{array}{l}22(71) \\
4(12.9) \\
3(9.7) \\
2(6.4)\end{array}$ & $\begin{array}{l}25(75.8) \\
4(12.1) \\
2(6.1) \\
2(6.1) \\
\end{array}$ & $\begin{array}{l}23(71.9) \\
6(18.8) \\
1(3.1) \\
2(6.2) \\
\end{array}$ & $\begin{array}{l}70(72.9) \\
14(14.5) \\
6(6.3) \\
6(6.3) \\
\end{array}$ & $\$ 0.899$ \\
\hline $\begin{array}{l}\text { Fuhrman grade }(n, \%) \\
1-2 \\
3-4\end{array}$ & $\begin{array}{l}18(58) \\
13(42)\end{array}$ & $\begin{array}{l}22(66.7) \\
11(33.3)\end{array}$ & $\begin{array}{l}22(68.8) \\
10(31.2)\end{array}$ & $\begin{array}{l}62(64.5) \\
34(35.5)\end{array}$ & $\$ 0.644$ \\
\hline $\begin{array}{l}\text { Pathological stage }(n, \%) \\
\text { T1a } \\
\text { T1b } \\
\text { T2a-T2b }\end{array}$ & $\begin{array}{l}13(41.9) \\
16(51.6) \\
2(6.4)\end{array}$ & $\begin{array}{l}15(45.5) \\
13(39.4) \\
5(15.2)\end{array}$ & $\begin{array}{l}17(53.1) \\
11(34.4) \\
4(12.5)\end{array}$ & $\begin{array}{l}45(46.8) \\
40(41.7) \\
11(11.5)\end{array}$ & +0.604 \\
\hline $\begin{array}{l}\text { TNM stage }(n, \%) \\
\text { Stage } 1 \\
\text { Stage } 2\end{array}$ & $\begin{array}{l}29(93.5) \\
2(6.5) \\
\end{array}$ & $\begin{array}{l}28(84.8) \\
5(15.2) \\
\end{array}$ & $\begin{array}{l}28(87.5) \\
4(12.5) \\
\end{array}$ & $\begin{array}{l}85(88.5) \\
11(11.5) \\
\end{array}$ & +0.537 \\
\hline $\begin{array}{l}\text { Presence of necrosis }(n, \%) \\
\text { Yes } \\
\text { No }\end{array}$ & $\begin{array}{l}4(12.9) \\
27(87.1)\end{array}$ & $\begin{array}{l}9(27.3) \\
24(72.7)\end{array}$ & $\begin{array}{l}7(21.9) \\
25(78.1)\end{array}$ & $\begin{array}{l}20(20.8) \\
76(79.2)\end{array}$ & +0.362 \\
\hline $\begin{array}{l}\text { eGFR (median, } \\
25^{\text {th }}-75^{\text {th }} \text { percentile) }\end{array}$ & $\begin{array}{l}95.46 \\
(78.98-108.56)^{\mathrm{a}} \\
\end{array}$ & $\begin{array}{l}81.96 \\
(69.27-91.38)^{b} \\
\end{array}$ & \begin{tabular}{|l|}
78.97 \\
$(72.44-89.01)^{b}$ \\
\end{tabular} & $\begin{array}{l}83.25 \\
(73.23-97.88) \\
\end{array}$ & $\S 0.007 / 0.003 / 0.637 *$ \\
\hline Follow-up period, median (min-max) month & $59(13-102)$ & $57(14-102)$ & $50(6-100)$ & $57(6-102)$ & $\S 0.571$ \\
\hline Local recurrence rate $(n, \%)$ & $1(3.2)$ & $1(3.0)$ & $7(21.9)$ & $9(9.4)$ & $\$ 0.012^{*}$ \\
\hline Distant metastasis rate $(\mathrm{n}, \%)$ & $1(3.2)$ & $3(9.1)$ & $8(25)$ & $12(12.5)$ & $\$ 0.025 *$ \\
\hline Cancer-specific survival rate (\%) & 96.8 & 90.9 & 78.1 & 88.5 & $\$ 0.059$ \\
\hline \multicolumn{6}{|c|}{$\begin{array}{l}\text { a, b, c: Groups with statistically significant differences were shown with different letters } \\
\text { There is no statistical difference between the groups indicated by the same letter. } \\
\text { ab: Group with no statistically significant difference from other two groups } \\
\text { † ANOVA } \ddagger \text { Chi-square } \S \text { Kruskal-Wallis * } p<0.05 \text { (There is a significant difference between groups) } \\
\text { BMl: Body mass index, TNM: Tumour-node-metastasis, } \\
\text { eGFR: Estimated glomerular filtration rate }\end{array}$} \\
\hline
\end{tabular}


BMI, eGFR and Framingham risk score were found to be more significant (Table 3). In addition, according to Spearman correlation analysis, a significant negative correlation was found between eGFR and Framingham risk score $(r=-0.380, p<0.001)$ (Figure 4).

\section{Discussion}

The tumor-related anatomical and histological factors affecting prognosis in RCC are TNM stage, Fuhrman tumor grade, RCC histological subtype, and tumor size. Nowadays, many nomograms and models have been defined for the development of recurrence and progression in both localized and metastatic disease before and after nephrectomy. The most important of these models as independent prognostic factors are TNM stage, Fuhrman degree and patient performance status.

The pathologic tumor stage in RCC is the most important prognostic factor alone, and the 5-year survival rate in T1-2N0M0 is 70-90\% (16). The 10-year cancer-specific survival rates for pathological stage T1a, T1b, T2 are 90-95\%, 80-85\% and $75 \%$, respectively (17). Large-sized, organ-confined tumors have been found to have a greater degree of clear cell tumor histology and a higher grade of Fuhrman (18).

In a multicentre study involving 5332 patients, the 5-year cancer-specific survival rates reported by Novara et al. (19) were $94.9 \%, 92.6 \%, 85.4 \%$ and $70 \%$ for pT1a, pT1b, pT2a,
pT2b, respectively. In a current study involving T1, T2 and T3a patients, local or distant recurrence was $21.57 \%$ and cancerspecific survival was $78.43 \%$ at $50.8 \pm 18.1$ months follow-up (20).

In RCC, the Fuhrman nuclear grade revealed a link between tumor stage, size, nodal involvement and systemic metastasis (21). When all pathological stages were compared, 5-year

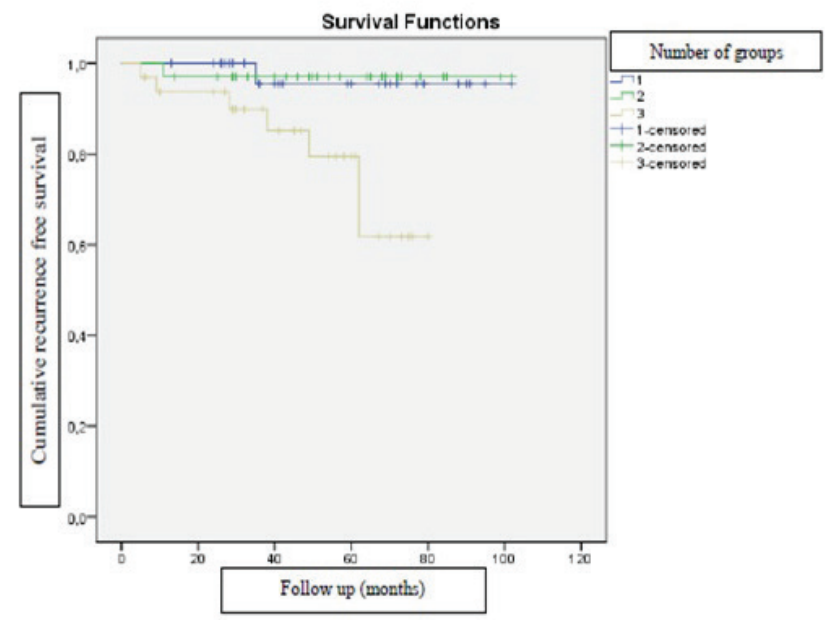

Figure 1. Graph of Kaplan-Meier analysis for predicted recurrence-free survival in three groups

\begin{tabular}{|c|c|c|c|c|c|c|c|}
\hline \multicolumn{8}{|c|}{ Predicted recurrence-free survival time (month) } \\
\hline & Mean & \multicolumn{2}{|c|}{$\% 95 \mathrm{Cl}$} & Median & \multicolumn{2}{|c|}{$\% 95 \mathrm{Cl}$} & $\mathrm{p}$ \\
\hline Group 1 & 98.9 & 93.1 & 104.7 & - & - & - & \multirow[t]{3}{*}{0.005} \\
\hline Group 2 & 99.2 & 93.9 & 104.5 & - & - & - & \\
\hline Total & 93.4 & 88.1 & 98.6 & - & - & - & \\
\hline \multicolumn{8}{|c|}{ Predicted metastasis-free survival time (month) } \\
\hline & \multirow{2}{*}{ Mean } & \multicolumn{2}{|c|}{$\% 95 \mathrm{Cl}$} & \multirow{2}{*}{ Median } & \multicolumn{2}{|c|}{$\% 95 \mathrm{Cl}$} & \multirow[t]{2}{*}{$\mathrm{p}$} \\
\hline & & Lower & Upper & & Lower & Upper & \\
\hline Group 1 & 92.9 & 86.9 & 97.5 & - & - & - & \multirow[t]{2}{*}{0.017} \\
\hline Total & 90.7 & 84.7 & 96.6 & - & - & - & \\
\hline \multicolumn{8}{|c|}{ Predicted cancer specific survival time (month) } \\
\hline & \multirow{2}{*}{ Mean } & \multicolumn{2}{|c|}{$\% 95 \mathrm{Cl}$} & \multirow{2}{*}{ Median } & \multicolumn{2}{|c|}{$\% 95 \mathrm{Cl}$} & \multirow[t]{2}{*}{$\mathrm{p}$} \\
\hline & & Lower & Upper & & Lower & Upper & \\
\hline Group 1 & 102.0 & 102.0 & 102.0 & 102.0 & - & - & \multirow[t]{4}{*}{0.024} \\
\hline Group 2 & 94.7 & 86.8 & 102.5 & - & - & - & \\
\hline Group 3 & 79.9 & 67.2 & 92.6 & - & - & - & \\
\hline Total & 92.2 & 86.2 & 98.2 & 102.0 & 72.6 & 131.3 & \\
\hline
\end{tabular}




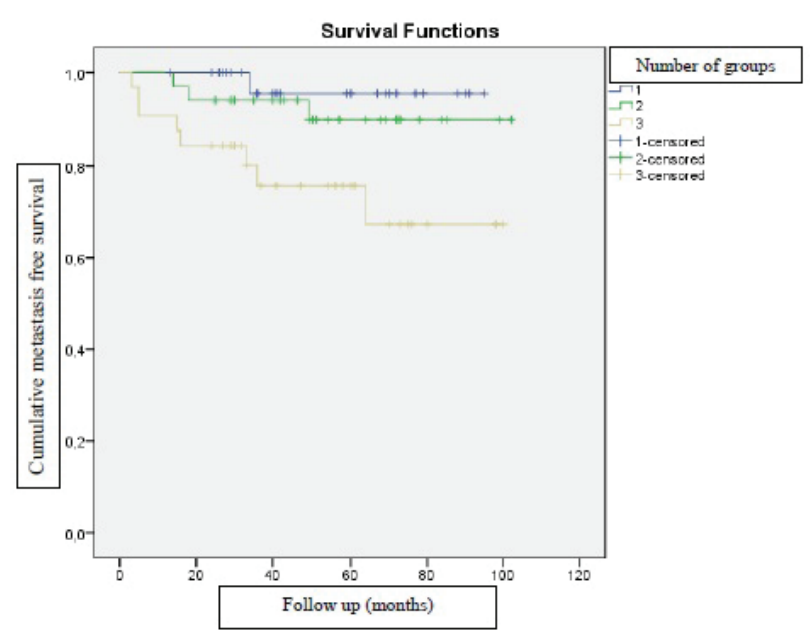

Figure 2. Graph of Kaplan-Meier analysis for predicted metastasis-free survival in three groups

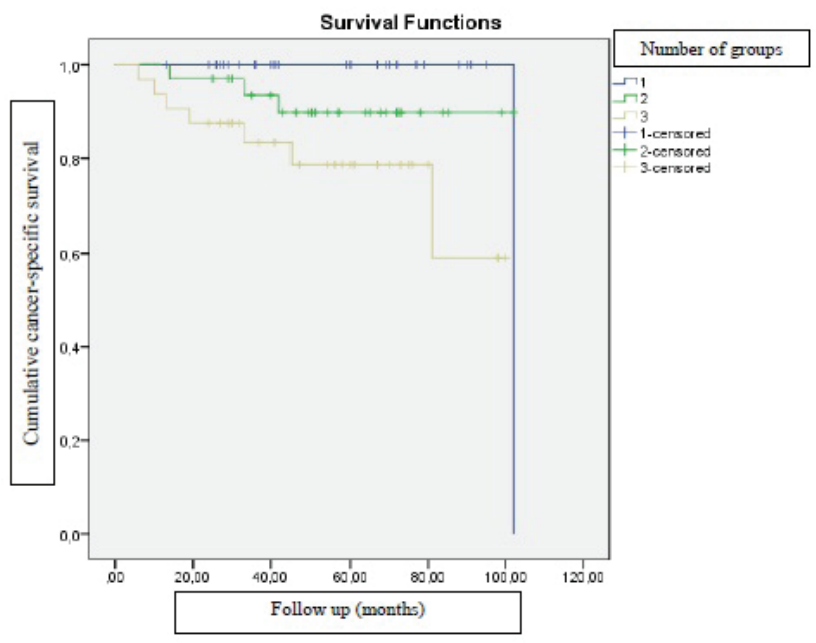

Figure 3. Graph of Kaplan-Meier analysis for predicted cancer-specific survival in three groups

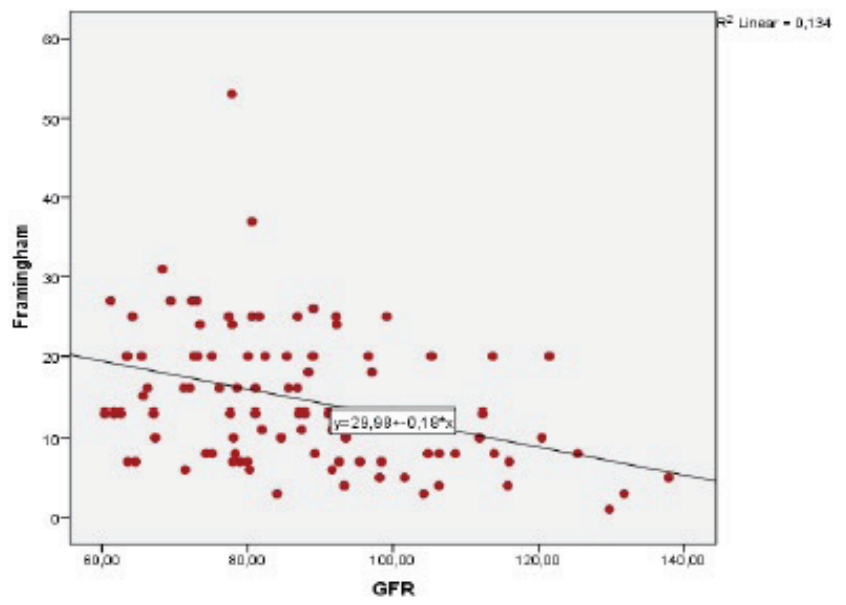

Figure 4. Graphical representation of the correlation between Framingham risk score and eGFR: Estimoted glomenular filtnotion note survival rates for Fuhrman grades I, II, III, IV were reported as $64 \%, 34 \%, 31 \%$ and $10 \%$, respectively, and this grading is known to be an important prognostic factor in organ-confined localized disease (22). As a matter of fact, in a multicentre study involving 5009 cases, local recurrence rates at 5 years after nephrectomy were observed as $17.1 \%, 23.9 \%, 11.3 \%$ and $4.2 \%$ for $\mathrm{T} 1 \mathrm{a}, \mathrm{T} 1 \mathrm{~b}, \mathrm{~T} 2 \mathrm{a}$ and $\mathrm{T} 2 \mathrm{~b}$, respectively, during median follow-up of 105 months, and recurrence rates have been reported to be higher in Fuhrman grade 3-4 cases (23).

During a median follow-up of 64 (6-102) months in T1a and T1b patients in our study, local recurrence rates were $9.75 \%$ and $14.28 \%$, distant metastasis rates were $9.75 \%$ and $25 \%$, and cancer specific survival rates were $92.5 \%$ and $86.35 \%$, respectively. Our oncologic results for T1 stage are consistent with current literature data. However, we could not make a significant survival analysis for T2 stage since there were 11 patients and there was no cancer-related mortality during the median 59 (13-99) months follow-up. During the median 57 (6-102) months follow-up of all patients in the $\mathrm{T} 1$ and T2 stages, local recurrence was $9.4 \%$, distant metastasis was $12.5 \%$, and cancer-specific survival was $88.5 \%$. Although we observed that Fuhrman grade 3-4 was an independent prognostic factor affecting both local recurrence and cancerspecific survival, we could not find a significant effect on the development of metastasis.

In the literature, there are many studies investigating the effect of metabolic syndrome, including impaired glucose tolerance /diabetes, obesity, high triglyceride levels, low HDL levels and hypertension on oncologic outcomes in $\operatorname{RCC}(8,9,24)$. Although there are some contradictory results, metabolic syndrome is thought to be a poor prognostic factor for RCC. It is known that the incidence of RCC increases approximately 4-6 times in patients with three or more metabolic syndrome components (8). It was observed that the tumor size and grade were significantly higher in the presence of metabolic syndrome and that there was a correlation between individual hypertension, diabetes and high triglyceride levels with tumor aggressiveness (9).

Kriegmair et al. (10) showed no significant individual effect of diabetes, obesity (BMl>30 $\left.\mathrm{kg} / \mathrm{m}^{2}\right)$, hypertension and hypertriglyceridemia on progression-free survival (PFS) in localized RCC. However, in the presence of metabolic syndrome consisting of all these components, it was observed that PFS was significantly shortened and cancer-specific survival did not change. When Kocher et al. (11) examined the components of the metabolic syndrome, they found that hypertension has the most significant relationship with high tumor stage, high Fuhrman grade, increased tumor size, increased nephrometry score and non-clear cell histological subtype in RCC.

Eskelinen et al. (12) found a significant relationship between the presence of hypertension and dyslipidemia in patients with local advanced stage RCC at the time of diagnosis and found that, among the metabolic syndrome components, only hypertension was an independent risk factor that increases cancer-related mortality (12). In accordance with these results, another study reported that the presence of type 2 diabetes alone was not found to be a negative prognostic factor for RCC 
(25).

When the literature is examined, it is seen that both the presence of metabolic syndrome and the individual components are investigated on the oncologic outcomes in localized RCC. In patients with no required lifestyle changes or medical treatment for blood pressure, lipid profile and body mass index, it is known that they have a risk of developing cardiovascular disease in 10-year follow-up as a result of the cumulative effect of the risk factors. We could not find any study investigating the oncologic outcomes of localized RCC patients classified according to this risk analysis during follow-up after nephrectomy.

Numerous nomograms and risk analyzes are available to estimate the risk of cardiovascular disease, with Framingham Heart Study results affecting most of them (26). The common goal of these risk analyzes is to quantitatively calculate the measurable and preventable risk factors on the development of cardiovascular disease. In this way, it is aimed to determine the appropriate treatment by changing the life style and behavior in the patients at risk.

Smoking, obesity and hypertension are the most important predisposing factors in RCC and are associated with a higher incidence of cancer. Although obesity is known to increase the incidence of RCC, in some studies, better oncologic outcomes have been reported during follow-up after nephrectomy in patients with high BMI $(20,27)$. In our study, although only three patients were in the obese category (BMI $\left.\geq 30 \mathrm{~kg} / \mathrm{m}^{2}\right)$, we observed that the increase in BMI was associated with more recurrence, distant metastasis and cancer-related mortality, and BMI values were significantly higher in group 3 .

Although the number of cigarettes smoked per day and duration of smoking directly affect RCC development, the incidence of RCC decreases by $30 \% 10$ years after smoking cessation (20). In our study, although smoking did not seem to affect oncologic outcomes in univariate and multivariate models, the smoking rate, which is a component of Framingham score, was significantly higher in group 3 where worse prognostic

\begin{tabular}{|c|c|c|c|c|c|c|c|c|}
\hline \multirow{3}{*}{$\begin{array}{l}\text { Development of local } \\
\text { recurrence }\end{array}$} & \multicolumn{4}{|c|}{ Univariate Model } & \multicolumn{4}{|c|}{ Multivariate Model } \\
\hline & \multirow[t]{2}{*}{$\mathrm{HR}$} & \multicolumn{2}{|l|}{$\% 95 \mathrm{Cl}$} & \multirow[t]{2}{*}{$p$} & \multirow[t]{2}{*}{ HR } & \multicolumn{2}{|l|}{$\% 95 \mathrm{Cl}$} & \multirow[t]{2}{*}{$p$} \\
\hline & & Lower & Upper & & & Lower & Upper & \\
\hline BMI & 1.877 & 1.381 & 2.552 & $<0.001$ & 1.779 & 1.161 & 2.725 & 0.008 \\
\hline Hypertension & 1.118 & 1.055 & 1.185 & $<0.001$ & - & - & - & - \\
\hline Total cholesterol & 1.023 & 1.009 & 1.038 & 0.001 & - & - & - & - \\
\hline $\mathrm{HDL}$ & 0.878 & 0.774 & 0.995 & 0.042 & - & - & - & - \\
\hline Fuhrman grade 3-4 & 3.902 & 1.560 & 9.756 & 0.004 & 5.049 & 1.388 & 18.363 & 0.014 \\
\hline eGFR & 0.942 & 0.891 & 0.995 & 0.033 & 0.932 & 0.866 & 1.003 & 0.044 \\
\hline \multirow[t]{2}{*}{ Framingham risk score } & 1.192 & 1.092 & 1.301 & $<0.001$ & 1.192 & 1.092 & 1.235 & $<0.001$ \\
\hline & \multicolumn{4}{|c|}{ Univariate Model } & \multicolumn{4}{|c|}{ Multivariate Model } \\
\hline \multirow{2}{*}{ Development of metastasis } & \multirow[t]{2}{*}{$\mathrm{HR}$} & \multicolumn{2}{|l|}{$\% 95 \mathrm{Cl}$} & \multirow[t]{2}{*}{$\mathrm{p}$} & \multirow[t]{2}{*}{$\mathrm{HR}$} & \multicolumn{2}{|l|}{$\% 95 \mathrm{Cl}$} & $p$ \\
\hline & & Lower & Upper & & & Lower & Upper & \\
\hline BMI & 1.755 & 1.364 & 2.258 & $<0.001$ & 1.755 & 1.364 & 2.258 & $<0.001$ \\
\hline Hypertension & 1.067 & 1.020 & 1.117 & 0.005 & - & - & - & - \\
\hline Total cholesterol & 1.023 & 1.010 & 1.035 & $<0.001$ & - & - & - & - \\
\hline eGFR & 0.932 & 0.885 & 0.981 & 0.007 & 0.947 & 0.899 & 0.998 & 0.043 \\
\hline \multirow[t]{2}{*}{ Framingham risk score } & 1.125 & 1.066 & 1.187 & $<0.001$ & 1.074 & 0.998 & 1.156 & 0.042 \\
\hline & \multicolumn{4}{|c|}{ Univariate Model } & \multicolumn{4}{|c|}{ Multivariate Model } \\
\hline \multirow{2}{*}{ Cancer spesific survival } & \multirow{2}{*}{$\begin{array}{l}\text { HR } \\
\text { Lower }\end{array}$} & \multicolumn{2}{|c|}{$\% 95 \mathrm{Cl}$} & \multirow[t]{2}{*}{ p } & \multirow{2}{*}{\begin{tabular}{|l|} 
HR \\
Lower
\end{tabular}} & \multicolumn{2}{|l|}{$\% 95 \mathrm{Cl}$} & \multirow[t]{2}{*}{$\mathbf{p}$} \\
\hline & & Upper & & & & Upper & & \\
\hline BMI & 2.161 & 1.563 & 2.989 & $<0.001$ & 2.161 & 1.563 & 2.898 & $<0.001$ \\
\hline Hypertension & 1.076 & 1.029 & 1.125 & 0.001 & - & - & - & - \\
\hline Presence of diabetes & 3.716 & 1.055 & 13.093 & 0.041 & - & - & - & - \\
\hline Total cholesterol & 1.019 & 1.006 & 1.033 & 0.004 & - & - & - & - \\
\hline Fuhrman grade 3-4 & 2.788 & 1.209 & 6.429 & 0.016 & - & - & - & - \\
\hline eGFR & 0.930 & 0.879 & 0.984 & 0.012 & 0.905 & 0.816 & 1.003 & 0.042 \\
\hline Framingham risk score & 1.139 & 1.076 & 1.205 & $<0.001$ & 1.087 & 1.020 & 1.159 & 0.011 \\
\hline
\end{tabular}


outcomes were observed. The incidence of hypertension and diabetes was also significantly higher in this high-risk group.

When all patients in our study were divided into groups according to Framingham risk score, local recurrence rate (21.9\%) and distant metastasis rate (25\%) were significantly higher, and predicted recurrence-free survival (66.4 months), metastasis-free survival (77 months) and cancer-specific survival (79.9 months) were significantly lower in group 3 with a high risk of developing cardiovascular disease. Although the cancerspecific survival rate was lower $(78.1 \%)$ in the high-risk group, it was not statistically significant $(\mathrm{p}=0.059)$.

As known, partial nephrectomy technique has gained significant role in small renal masses (especially in $\mathrm{T} 1$ stage) based on the idea that nephron loss after nephrectomy may increase the course of chronic kidney disease (CKD). An eGFR value of $45-60 \mathrm{~mL} / \mathrm{min} / 1.73 \mathrm{~m}^{2}$, which is the third stage CKD indicator, was observed in $65 \%$ after radical nephrectomy and $20 \%$ after partial nephrectomy. The rate of severe CKD (eGFR $<45 \mathrm{~mL}$ / $\mathrm{min} / 1.73 \mathrm{~m}^{2}$ ) was $36 \%$ after radical nephrectomy and $5 \%$ after partial nephrectomy (28). It is known that the decrease in eGFR after nephrectomy leads to an increase in cardiovascular disease and mortality, and a decrease in overall survival $(29,30)$. Ahmedov et al. (20) demonstrated that pre-operatively lower eGFR values also adversely affected cancer-specific survival and recurrence-free survival. In our study, preoperative eGFR was $>60 \mathrm{~mL} / \mathrm{min} / 1.73 \mathrm{~m}^{2}$ in all patients, however, significantly lower eGFR values were found in group 3 with a high risk of cardiovascular disease within 10 years and these patients had worse oncologic outcomes during follow-up. In univariate and multivariate analyzes, we observed that preoperative eGFR level affected local recurrence, metastasis rates and cancer-specific survival. In accordance with these findings, we also showed a significant negative correlation between eGFR and Framingham risk score $(r=-0.380, p<0.001)$. This suggests that relatively lower preoperative eGFR is an independent factor that adversely affects overall survival by increasing both RCC-related mortality and cardiovascular risk.

\section{Limitations of the Study}

The retrospective design of our study, the low number of patients, the lack of randomization, and the fact that the followup results belong to a single center are the main limiting factors.

\section{Conclusion}

In patients with localized-stage RCC who are at high risk of developing cardiovascular disease, more local recurrence, distant metastasis and cancer-related mortality rates can be observed postoperatively despite curative treatment with nephrectomy. Therefore, we suggest that these patients should be followed more carefully in the post-nephrectomy period. The results should be supported with prospective, randomized, multicentre, large-scale studies with longer follow-up periods and the issue should be further clarified.

\section{Ethics}

Ethics Committee Approval: Ethical committee approval was not obtained since it is a retrospective study.
Informed Consent: Patients were pre-operatively informed about the use of oncologic follow-up data such as recurrence, metastasis development and survival analysis in various oncological studies without revealing patient names and identity information. The data of patients who did not consent were not used.

Peer-review: Externally and Internally peer-reviewed.

\section{Author Contributions}

Surgical and Medical Application: H.B., Concept: H.B., Design: I.S., Data Collection or Processing: I.S., Analysis or Interpretation: I.S., H.B., Literature Search: I.S., Writing: I.S.

Conflict of Interest: No conflict of interest was declared by the authors.

Financial Support: No financial support was received from any institution or person for this study.

\section{References}

1. Rendon RA, Kapoor A, Breau R, et al. Surgical management of renal cell carcinoma: Canadian Kidney Cancer Forum Consensus. Can Urol Assoc J 2014;8:E398-E412.

2. Lipworth L, Tarone RE, McLaughlin JK. The epidemiology of renal cell carcinoma. J Urol 2006;176:2353-2358.

3. Ljungberg B, Albiges $L$, Bensalah $K$, et al. EAU guidelines on renal cell carcinoma: 2018 update. http://uroweb.org/guideline/ renal-cell-carcinoma/

4. Hamidi N,Süer E,Gökçe Mi, Bedük Y. The Affect of Preoperative Neutrophil-Lymphocyte Ratio on Distant Metastasis and Disease Specific Survival in Patients Who Underwent Nephrectomy for Localized Renal Cell Carcinoma. Van Med J 2017;24:135-140.

5. Pichler M, Hutterer GC, Stoeckigt $C$, et al. Validation of the pretreatment neutrophil lymphocyte ratio as a prognostic factor in a large European cohort of renal cell carcinoma patients. Br J Cancer 2013;111:901-907.

6. Gökçe MI, Hamidi N, Esen B, et al. Patolojik T1a Evreli Şeffaf Hücre Renal Hücreli Kanser Hastalarında Nüksü Öngörmede İnflamasyon Belirteçlerinin Rolünün Değerlendirilmesi. Üroonkoloji Bülteni 2016;15:18-21.

7. Rodriguez-Covarrubias F, Gomez-Alvarado MO, Sotomayor M, et al. Time to recurrence after nephrectomy as a predictor of cancerspecific survival in localized clear-cell renal cell carcinoma. Urol Int 2011; 86:47-52.

8. Bulut $S$, Aktas BK, Erkmen AE, et al. Metabolic syndrome prevalence in renal cell cancer patients.Asian Pac J Cancer Prev 2014;15:7925-7928.

9. Ozbek E, Otunctemur A, Sahin S, et al. Renal cell carcinoma is more aggressive in Turkish patients with the metabolic syndrome. Asian Pac J Cancer Prev 2013;14:7351-7354.

10. Kriegmair MC, Mandel P, Porubsky S, et al. Metabolic Syndrome Negatively Impacts the Outcome of Localized Renal Cell Carcinoma. Horm Cancer 2017;8:127-134.

11. Kocher NJ, Rjepaj $\mathrm{C}$, Robyak $\mathrm{H}$, et al. Hypertension is the primary component of metabolic syndrome associated with pathologic features of kidney cancer. World J Urol 2017;35:67-72.

12. Eskelinen TJ, Kotsar A, Tammela TLJ, Murtola TJ. Components of metabolic syndrome and prognosis of renal cell cancer. Scand J Urol 2017; 51:435-441.

13. National Cholesterol Education Program (NCEP) Expert Panel on Detection, Evaluation, and Treatment of High Blood Cholesterol in Adults (Adult Treatment Panel III). Third Report of the National Cholesterol Education Program (NCEP) Expert Panel on Detection, Evaluation, and Treatment of High Blood Cholesterol in Adults (Adult Treatment Panel III) final report. Circulation 2002;106:3143-3421. 
14. Levy D, Wilson PWF, Anderson KM, et al. Stratifying the patient at risk from coronary disease: new insights from the Framingham Heart Study. Am Heart J 1990;119:712-717.

15. Kannel W, McGee D, Gordon T. A general cardiovascular risk profile: the Framingham Study. Am J Cardiol 1976;38:46-51.

16. Kanao K, Mizuno R, Kikuchi E, et al. Preoperative prognostic nomogram (probability table) for renal cell carcinoma based on TNM classification. J Urol 2009; 181:480-485.

17. Patard JJ, Dorey FJ, Cindolo L, et al. Symptoms as well as tumor size provide prognostic information on patients with localized renal tumors. J Urol 2004;172:2167-2171.

18. Thompson RH, Kurta JM, Kaag M, et al. Tumor size is associated with malignant potential in renal cell carcinoma cases. J Urol 2009;181(5):2033-2036.

19. Novara G, Ficarra V, Antonelli A, et al. Validation of the 2009 TNM version in a large multi-institutional cohort of patients treated for renal cell carcinoma: are further improvements needed? Eur Urol 2010;58:588-595.

20. Ahmedov V, Kizilay F, Cüreklibatir I. Prognostic Significance of Body Mass Index and Other Tumor and Patient Characteristics in NonMetastatic Renal Cell Carcinoma. Urol J 2018;15:96-103.

21. Ficarra V, Novara G, Galfano A, et al. The 'Stage, Size, Grade and Necrosis' score is more accurate than the University of California Los Angeles Integrated Staging System for predicting cancer-specific survival in patients with clear cell renal cell carcinoma. BJU Int 2009;103:165-170.

22. Fuhrman SA, Lasky LC, Limas C. Prognostic significance of morphologic parameters in renal cell carcinoma. Am J Surg Pathol 1982;6:655-663.
23. Brookman-May S, May M, Shariat SF et al. Features associated with recurrence beyond 5 years after nephrectomy and nephron-sparing surgery for renal cell carcinoma: development and internal validation of a risk model (PRELANE score) to predict late recurrence based on a large multicenter database (CORONA/SATURN Project). Eur Urol 2013;64:472-477.

24. Zhang GM, Zhu Y, Ye DW. Metabolic syndrome and renal cell carcinoma. World J Surg Oncol 2014;12:236-245.

25. Antonelli A, Arrighi N, Corti S, et al. Pre-existing type-2 diabetes is not an adverse prognostic factor in patients with renal cell carcinoma: a single-center retrospective study. Urol Oncol 2013;31:1310-1315.

26. Tekkeşin N, Kılınç C. Investigation of Framingham Risk Factors in Turkish adults. J Clin Exp Invest 2011;2:42-49.

27. Kamat AM, Shock RP, Naya Y, et al. Prognostic value of body mass index in patients undergoing nephrectomy for localized renal tumors. Urology 2004;63:46-50.

28. Russo P, Huang W. The medical and oncological rationale for partial nephrectomy for the treatment of T1 renal cortical tumors. Urol Clin North Am 2008;35:635-643.

29. Go AS, Chertow GM, Fan D, et al. Chronic kidney disease and the risks of death, cardiovascular events, and hospitalization. N Engl J Med 2004;351:1296-1305.

30. Kambara T, Tanimoto R, Araki M, et al. Renal Function after Nephrectomy Influences the Risk of Cardiovascular Events. Acta Med Okayama 2018;72:241-247. 